\title{
HUBUNGAN TINGKAT STRES DENGAN PERUBAHAN POLA MENSTRUASI PADA REMAJA
}

\author{
The Correlation Between Stress Level and Menstrual Pattern in Teenagers \\ Pande Putu Novi Ekajayanti, Pande Putu Indah Purnamayanthi \\ Program Studi Diploma III Kebidanan, Stikes Bina Usada Bali \\ Jl. Raya Padang Luwih, Dalung, Badung, Bali telp. (0361) 9072036 \\ E-mail:pandenovi18@gmail.com
}

\begin{abstract}
ABSTRAK
Latar belakang: Masa remaja merupakan masa transisi dalam rentang kehidupan manusia yang menghubungkan masa kanak-kanak dan masa dewasa. Salah satu gangguan yang dialami remaja adalah stres. Pada saat ini, banyak fakta yang mengungkapkan hubungan antara stres terhadap perubahan poal menstruasi yang merupakan masalah kesehatan bagi wanita. Penelitian ini bertujuan untuk mengetahui hubungan tingkat stres terhadap perubahan pola menstruasi pada remaja putri.

Subjek dan Metode: Penelitian menggunakan desain penelitian cross sectional. Subjek penelitian adalah seluruh remaja putri kelas IX di SMP Negeri 2 Denpasar yang berjumlah 92 sampel. Teknik pengambilan sampel secara purposive sampling. Pengumpulan data menggunakan kuesioner. Analisa statistik menggunakan Chi-Square Test.

Hasil: Terdapat hubungan tingkat stres terhadap perubahan pola menstruasi pada remaja putri dengan nilai $\mathrm{p}$ (value) sebesar 0.01 dan $\alpha=0,05$.
\end{abstract}

Kesimpulan: Terdapat hubungan tingkat stres terhadap perubahan pola menstruasi.

Kata kunci: Remaja Putri, Perubahan Pola Menstruasi, Tingkat Stres 


\begin{abstract}
Background: Adolescence is a transition period in the span of human life that connects childhood and adulthood. One disorder experienced by adolescents is stress. At this time, there are many facts that reveal the relationship between stress and menstrual changes that are a health problem for women. This correlational study aims to determine the relationship of stress levels to changes in menstrual patterns in teenagers.

Subjects and Method: The study used a cross sectional research design. The subjects of the study were all 92 class IX young women in SMP Negeri 2 Denpasar. The sampling technique was purposive sampling. Data collection using a questionnaire. Statistical analysis using the Chi-Square Test.
\end{abstract}

Results: The results showed that there was a relationship between stress levels and changes in menstrual patterns in teenagers with $p$ (value) of 0.01 and $\alpha=0.05$.

Conclusion: There is a relation between stress levels and changes in menstrual patterns.

Keywords: Young Women, Changes in Menstrual Patterns, Stress Levels

\section{PENDAHULUAN}

Masa remaja merupakan masa transisi dalam rentang kehidupan manusia yang menghubungkan masa kanak-kanak dan masa dewasa. Menurut WHO batasan usia remaja adalah 12 sampai 24 tahun, sedangkan menurut Survei Kesehatan Reproduksi Remaja Indonesia (SKRRI) tahun 2007, remaja adalah laki-laki dan perempuan yang belum kawin dengan batasan usia meliputi 15-24 tahun $^{[1]}$.

Dalam periode ini terjadi perubahan yang sangat pesat dalam dimensi fisik, mental, dan sosial. Masa ini juga merupakan periode pencarian identitas diri, sehingga remaja sangat mudah terpengaruh oleh lingkungan. Umumnya proses pematangan fisik lebih cepat dari pematangan psikososialnya. Karena itu seringkali terjadi ketidakseimbangan yang menyebabkan remaja menjadi sangat sensitif dan rawan terhadap stres. Perkembangan masa remaja yang disertai dengan berkembangnya kapasitas intelektual, stres, dan harapan baru yang dialami remaja membuat remaja mudah mengalami gangguan, baik berupa gangguan pikiran, perasaan, maupun gangguan perilaku ${ }^{[2]}$.

Salah satu gangguan yang dialami remaja adalah stress. Stres dapat diderita oleh siapa saja dan tidak memandang status orang itu kaya maupun miskin serta tidak memandang usia apakah anak-anak, remaja, atau orang tua, serta tidak memandang status sosial seseorang. Stres merupakan suatu respon fisiologis, psikologis, dan perilaku dari manusia yang mencoba untuk mengadaptasi dan mengatur baik tekanan internal dan eksternal. Sedangkan stressor adalah kejadian, situasi, seseorang atau suatu obyek yang dilihat sebagai unsur yang menimbulkan stres dan menyebabkan reaksi stres sebagai hasilnya. Stressor sangat bervariasi bentuk dan macamnya, mulai dari sumber-sumber psikososial dan perilaku seperti frustrasi, cemas dan kelebihan sumber bioekologi dan fisik seperti bising, polusi, temperatur, dan gizi. Dalam pengaruhnya terhadap pola menstruasi, stres melibatkan sistem neuroendokrinologi sebagai sistem yang besar peranannya dalam reproduksi wanita $^{[2]}$.

Semua bentuk stres akan menghasilkan reaksi pada tubuh. Respon tubuh terhadap stres meliputi 1400 reaksi fisik dan kimiawi serta melibatkan lebih 30 jenis hormon dan neurotransmitter yang berbeda. Disekresikannya hormon stres secara berlebihan dapat merusak sel, jaringan, dan organ tubuh lainnya. Salah satu dampak yang paling terlihat dari stres ini yaitu masalah kewanitaan ${ }^{[3]}$. 
Salah satu tanda kedewasaan seorang perempuan adalah menstruasi. Menstruasi merupakan proses yang kompleks dan harmonis dari serebrum, hipotalamus, hipofisis, alat-alat genital, korteks adrenal, kelenjar tiroid, prostaglandin, dan serotonin. Namun, variasi dari pola menstruasi dan gangguan menstruasi sering terjadi ${ }^{[4]}$. Studi ${ }^{[5]}$ menyatakan bahwa wanita usia reproduksi memiliki masalah terhadap menstruasi yang abnormal, seperti sindrom premenstruasi dan menstruasi yang tidak teratur. Prevalensi pola menstruasi yang abnormal berdasarkan evaluasi medis, terdapat $9-13 \%$ wanita usia reproduksi mengalami menstruasi yang tidak teratur. Pelajar/ maharemaja putri lebih sering menunjukkan variasi menstruasi yang bermasalah, seperti dismenorea, menoragia, dan menstruasi tidak teratur.

$$
\text { Banyak fakta yang }
$$

mengungkapkan hubungan antara stres terhadap perubahan pola menstruasi yang merupakan masalah kesehatan bagi wanita $^{[6]}$. Berdasarkan data yang ditemukan menunjukkan bahwa perubahan pola menstruasi yang abnormal berhubungan terhadap stres psikologi, dan juga menjelaskan bahwa sewaktu stres terjadi aktivasi aksis hipotalamuspituitari-adrenal bersama-sama terhadap sistem saraf autonom yang menyebabkan beberapa perubahan, diantaranya pada sistem reproduksi yakni pola menstruasi yang abnormal ${ }^{[6]}$.

Berdasarkan studi pendahuluan yang telah peneliti lakukan di SMP N 2 Denpasar pada 10 remaja putri kelas IX ditemukan bahwa 7 remaja putri mengatakan pola menstruasinya tidak teratur sejak berada di kelas IX. Ketujuh remaja putri mengatakan salah satu pemicu kemungkinan berubahnya pola menstruasi mereka adalah karena ketegangan manghadapi persiapan ujian yang membuat mereka stres. Sisanya mengatakan pola menstruasi masih sama terhadap kelas sebelumnya walaupun akan menghadapi persiapan ujian. Dari latar belakang diatas peneliti tertarik untuk meneliti tentang hubungan stres terhadap perubahan pola menstruasi pada remaja putri. Peneliti memilih remaja putri SMP sebagai objek penelitian ini karena pada usia remaja seseorang akan cenderung mengalami perubahan sikap maupun emosional yang ada dalam dirinya. Hal tersebut lebih mudah ditemukan dibandingkan pada remaja putri SMA.

\section{SUBJEK DAN METODE}

Penelitian ini menggunakan analitik cross sectional. Populasi dalam penelitian ini adalah seluruh remaja putri kelas IX di SMPN 2 Denpasar tahun ajaran 2018/ 2019 berjumlah 103 orang. Teknik sampling menggunakan non probability/ non random sampling dengan purposive sampling. Sampel dalam penelitian ini adalah seluruh remaja putri kelas IX di SMPN 2 Denpasar sebanyak 92 orang, dengan memenuhi kriteria inklusi yakni tercatat sebagai remaja putri kelas IX di SMPN 2 Denpasar, sudah mengalami menstruasi, dan bersedia menjadi responden. Sedangkan kriteria eksklusi yakni mengalami Amenore Sekunder.

\section{HASIL \\ Karakteristik Responden}

Seluruh responden berjenis kelamin perempuan dan berumur sekitar 14-15 tahun.

\section{Analisis Univariat \\ Berdasarkan tabel 1 diketahui responden dengan tingkat stres berat sebanyak 9 responden (10\%), tingkat stres sedang sebanyak 24 responden (26\%), dan tingkat stres ringan sebanyak 59 responden (64\%). Sedangkan 74 responden $(80 \%)$ tidak mengalami perubahan pola menstruasi dan 18 responden (20\%) mengalami perubahan pola menstruasi.}

\section{Analisis Bivariat}

Tabel 2 menunjukkan proporsi pada responden dengan tingkat stres berat 
yang tidak mengalami perubahan pola menstruasi sebanyak 1 responden (11\%) dan responden yang mengalami perubahan menstruasi sebanyak 8 responden (89\%). Responden dengan tingkat stres sedang yang tidak mengalami perubahan pola menstruasi sebanyak 17 responden $(71 \%)$ dan mengalami perubahan pola menstruasi sebanyak 7 responden (29\%). Serta responden dengan tingkat stres ringan yang tidak mengalami perubahan pola menstruasi sebanyak 56 responden $(95 \%)$ dan sebanyak 3 responden (5\%) mengalami perubahan pola menstruasi.

Hasil uji stastistik menggunakan Chi Square diperoleh 36,751, sig 0,000, yang artinya $p$ value sebesar 0,01 dan $\alpha$ sebesar 0,05 yang berarti $\mathrm{p}$ value lebih kecil dari $\alpha$. Hasil ini menunjukkan ada hubungan tingkat stres dengan perubahan pola menstruasi.

\section{Tabel 1. Analisis Univariat}

\begin{tabular}{lcc}
\hline \multicolumn{1}{c}{ Variabel } & $\begin{array}{c}\text { Frekuensi } \\
(\mathbf{n})\end{array}$ & $\begin{array}{c}\text { Persentase } \\
(\boldsymbol{\%})\end{array}$ \\
\hline Tingkat stress & & \\
Berat & 9 & 10 \\
Sedang & 24 & 26 \\
Ringan & 59 & 64 \\
Perubahan & & \\
pola & & \\
menstruasi & & \\
Tidak & 74 & 80 \\
Ya & 18 & 20 \\
\hline
\end{tabular}

Tabel 2. Hubungan Tingkat Stres terhadap Perubahan Pola Menstruasi

\begin{tabular}{lccccc}
\hline \multicolumn{1}{c}{ Tingkat } & \multicolumn{4}{c}{$\begin{array}{c}\text { Perubahan Pola } \\
\text { Menstruasi }\end{array}$} & P \\
\cline { 1 - 5 } & \multicolumn{4}{c}{ Tidak } & \multicolumn{3}{c}{ Ya } & \\
Berat & F & \% & F & \% & \\
Sedang & 1 & 11 & 8 & 89 & 0.01 \\
Ringan & 17 & 71 & 7 & 29 & \\
\hline
\end{tabular}

\section{PEMBAHASAN}

Menstruasi adalah proses alamiah yang terjadi pada perempuan. Menstruasi merupakan perdarahan yang teratur dari uterus sebagai tanda bahwa organ kandungan telah berfungsi matang.
Umumnya, remaja yang mengalami menarche adalah pada usia 12 sampai dengan 16 tahun. Periode ini akan mengubah perilaku dari beberapa aspek, misalnya psikologi dan lainnya. Stres sebagai suatu respon dari tubuh dalam menghadapi suatu stressor berlebih. Stres adalah reaksi/ respons tubuh terhadap stressor psikososial (tekanan mental/ beban kehidupan). Gambaran tingkat stres dengan pola menstruasi pada penelitian ini ditunjukkan dari jawaban responden dalam kuesioner yang disebarkan. Secara umum perubahan pola menstruasi ada tiga macam yaitu polimenore, oligomenore, dan amenore. Pada polimenorea siklus menstruasi lebih pendek dari biasa (kurang dari 21 hari) ${ }^{[9]}$.

Adanya perubahan pola menstruasi merujuk kepada sebab yang timbul dalam kehidupan wanita, seperti gangguan gizi, gangguan metabolisme, tumor, penyakit infeksi, dan lain-lain. Berbagai macam perubahan emosi akibat suatu stressor berkaitan dengan adanya fluktuasi hormonal selama pola menstruasi ${ }^{[10]}$.

Kebanyakan wanita mengalami sejumlah perubahan dalam pola menstruasi selama masa reproduksi. Dalam pengaruhnya terhadap pola menstruasi, stres melibatkan sistem neuroendokrinologi sebagai sistem yang berperan besar dalam reproduksi wanita ${ }^{[2]}$. Hasil penelitian diinterpretasikan dalam dua kategori yaitu tingkat stres dan perubahan pola menstruasi. Pada tabel silang diperoleh kecenderungan semakin tinggi tingkat stres maka semakin tinggi pula adanya perubahan pola menstruasi. Hal ini diperoleh karena adanya tingkatan stres pada seseorang khususnya seorang remaja putri akan berpengaruh terhadap perubahan pola hormonal sehingga siklus menstruasi yang dialami juga akan mengalami perubahan.

\section{SIMPULAN}

Ada hubungan yang signifikan antara tingkat stres terhadap perubahan pola menstruasi pada remaja putri. 
Penelitian selanjutnya dapat disarankan untuk melakukan pengkajian lebih mendalam tentang faktor yang mempengaruhi perubahan pola menstruasi dimana salah satunya adalah akibat dari adanya stres.

\section{DAFTAR PUSTAKA}

1. Wijaya. 2009. Metode penelitian kebidanan dan analisa data. Yogyakarta: Maha Medika.

2. Sriati. 2008. Panduan tentang stres. Jakarta: Salemba Medika.

3. Harya. 2011. Konsep dan penerapan metodelogi penelitian ilmu keperawatan. Jakarta: Salemba Medika.

4. Lee. 2006. Konsep metode penelitian kesehatan. Bandung: Alfabeta.

5. Saerang A, Suparman E, Lengkong RA. 2014. Hubungan antara stres dengan pola menstruasi pada mahasiswi fakultas kedokteran universitas sam ratulangi manado angkatan 2010. Jurnal e-Clinic (eCl). 2: (3).

6. Kaplan, Manuck. 2014. Metode penelitian kebidanan dan teknik analisis data. Jakarta: Salemba Medika.

7. Nursalam. 2013. Konsep dan penerapan metodologi penelitian ilmu keperawatan pedoman skripsi tesis dan instrumen penelitian keperawatan. Jakarta: Salemba Medika.

8. Kusmiran E. 2011. Kesehatan reproduksi remaja dan wanita. Jakarta: Salemba Medika.

9. Wiknjosastro. 2012. Panduan kesehatan reproduksi wanita. Bandung: Alfabeta. 